\title{
A Novel Approach in Crude Enzyme Laccase Production and Application in Emerging Contaminant Bioremediation
}

\author{
Luong N. Nguyen ${ }^{1, *} \mathbb{C}^{-}$, Minh T. Vu ${ }^{1}{ }^{1}$, Md Abu Hasan Johir ${ }^{1}$, Nirenkumar Pathak ${ }^{1}$, \\ Jakub Zdarta ${ }^{2}$ (1) , Teofil Jesionowski ${ }^{2}$ 'D, Galilee U. Semblante ${ }^{3}$, Faisal I. Hai ${ }^{4}$, \\ Hong Khanh Dieu Nguyen ${ }^{5}$ and Long D. Nghiem ${ }^{1}$ \\ 1 Centre for Technology in Water and Wastewater, School of Civil and Environmental Engineering, \\ University of Technology Sydney, Ultimo, NSW 2220, Australia; \\ truongminh.vu@student.uts.edu.au (M.T.V.); Mohammed.johir@uts.edu.au (M.A.H.J.); \\ Nirenkumar.pathak@uts.edu.au (N.P.); duclong.nghiem@uts.edu.au (L.D.N.) \\ 2 Faculty of Chemical Technology, Institute of Chemical Technology and Engineering, \\ Poznan University of Technology, Berdychowo 4, 60965 Poznan, Poland; \\ jakub.zdarta@put.poznan.pl (J.Z.); teofil.jesionowski@put.poznan.pl (T.J.) \\ 3 Technical Services, Western Sydney University, Kingswood, NSW 2747, Australia; \\ g.semblante@westernsydney.edu.au \\ 4 Strategic Water Infrastructure Lab, School of Civil, Mining and Environmental Engineering, \\ University of Wollongong, Wollongong, NSW 2522, Australia; Faisal@uow.edu.au \\ 5 School of Chemical Engineering, Ha Noi University of Science and Technology, Ha Noi 100000, Vietnam; \\ hong.nguyenkhanhdieu@hust.edu.vn \\ * Correspondence: luongngoc.nguyen@uts.edu.au; Tel.: +61-0468-863-865
}

Received: 8 May 2020; Accepted: 27 May 2020; Published: 29 May 2020

\begin{abstract}
Laccase enzyme from white-rot fungi is a potential biocatalyst for the oxidation of emerging contaminants (ECs), such as pesticides, pharmaceuticals and steroid hormones. This study aims to develop a three-step platform to treat ECs: (i) enzyme production, (ii) enzyme concentration and (iii) enzyme application. In the first step, solid culture and liquid culture were compared. The solid culture produced significantly more laccase than the liquid culture (447 vs. $74 \mu \mathrm{M} / \mathrm{min}$ after eight days), demonstrating that white rot fungi thrived on a solid medium. In the second step, the enzyme was concentrated 6.6 times using an ultrafiltration (UF) process, resulting in laccase activity of $2980 \mu \mathrm{M} / \mathrm{min}$. No enzymatic loss due to filtration and membrane adsorption was observed, suggesting the feasibility of the UF membrane for enzyme concentration. In the third step, concentrated crude enzyme was applied in an enzymatic membrane reactor (EMR) to remove a diverse set of ECs (31 compounds in six groups). The EMR effectively removed of steroid hormones, phytoestrogen, ultraviolet (UV) filters and industrial chemical (above 90\%). However, it had low removal of pesticides and pharmaceuticals.
\end{abstract}

Keywords: crude enzyme laccase; white-rot fungi; membrane filtration; emerging contaminants; enzymatic degradation; enzymatic membrane reactor

\section{Introduction}

The occurrence of emerging contaminants (ECs) in water and wastewater has been identified as a critical environmental and health issue. The EC concentration in water bodies varies from a few nanograms to several micrograms per liter [1-3]. Although ECs occur only at trace level [3], there is compelling evidence that biologically active compounds such as pesticides, steroid hormones, pharmaceuticals, industrial chemicals, phytoestrogens can cause endocrine disruption as well as 
inhibiting the sexual and reproductive growth of wildlife [3,4]. This portends a potential impact to greater ecology as well as human health. Thus, the remediation of ECs has been of great interest in recent years. Research efforts have led to innovations in remediation methods (e.g., membrane filtration, advanced oxidation process, membrane bioreactor, and activated carbon adsorption). These methods are based on physical, chemical and biological mechanisms. The membrane filtration process (i.e., nanofiltration and reverse osmosis) can effectively separate ECs with validated data from pilot and full-scale studies [5-7]. However, the treatment of nanofiltration (NF) and reverse osmosis (RO) concentrate is required since it contains a high level of ECs. Advanced oxidation process and activated carbon adsorption have also gained attention for their effectiveness in EC removal $[4,8]$. These methods have been used in a secondary or tertiary treatment because of the influence of high bulk organic content or high turbidity, which require high UV or ozone and activated carbon dosage. Membrane bioreactor (MBR) technology has been developed as an alternative to the conventional activated sludge process. The research data showed that MBR effectively removes hydrophobic (i.e., adsorption on sludge) and readily biodegradable materials by the bacteria community, and, less effectively, the hydrophilic and biologically persistent ECs $[9,10]$. Recent development in the enzymatic transformation of ECs that are persistent to bacterial degradation is a promising eco-friendly concept [11].

Lignin modifying enzymes, such as laccase from white-rot fungi, are potential biological agents for the oxidation of ECs. Laccase is one of the lignin modifying enzymes produced extracellularly by white-rot fungi when they degrade plant materials for growth. Since their discovery, enzymes have been applied for detoxifying and decolorizing in the pulp industry. Recently, laccase has been used to biodegrade contaminants due to its oxidation capacity in phenolic and some non-phenolic compounds [11,12]. Enzyme laccase in both crude and purified forms has been demonstrated to biodegrade ECs in batch and continuous experiments [11,13]. However, the high cost and loss of enzyme during the continuous application are two major roadblocks for the widespread application of this promising biotechnology.

Because ECs present in aqueous solutions, previous studies aimed to culture white-rot fungi using solid-free media. This approach is challenged by the low-volume production and high cost [14]. Solid-state culture can increase laccase production because white-rot fungi naturally prefer moist conditions. However, the solid state culture entails extraction and purification steps before its application [14,15]. Applying a membrane process to prevent enzyme washout in the enzyme application process is advantageous $[13,16]$. A few studies have showed promising results in enzyme retention as well EC removal using membranes $[13,16,17]$. However, regular enzyme addition is necessary due to enzyme denaturation, suggesting that an enzyme source that provides high amounts of enzyme is needed for this approach to be successful.

This study aims to develop an end-to-end enzyme-based platform that delivers a complete functional solution for EC treatment. The platform has three steps: enzyme production, enzyme concentration, and enzyme application. The enzyme production in liquid and solid culture was compared side by side to determine yield and efficiency. Crude enzyme from both cultures was concentrated in an ultrafiltration (UF) membrane. Finally, the concentrated crude enzyme solution was used to access the removal efficiency of $31 \mathrm{ECs}$ in an enzymatic membrane reactor (EMR). This study will pave the way for the future development in the enzymatic degradation of pollutants.

\section{Materials and Methods}

\subsection{Liquid and Solid Culture of White-Rot Fungi (WRF) for Enzyme Production}

Stock pure cultures (i.e., $1 \mathrm{~g}$ pellet) of Pleurotus ostreatus (ATCC 34675) were purchased from the American Type Culture Collection, Manassas, VA, USA. The stock was sub-cultured on malt extract agar $(41 \mathrm{~g} / \mathrm{L})$ Petri dishes in an incubator at $28{ }^{\circ} \mathrm{C}$ and $60 \%$ humidity. The resultant cultures were then stored at $4{ }^{\circ} \mathrm{C}$ for future experiments. 
Malt extract broth (Merck, Darmstadt, Germany) was used to developed liquid culture at a concentration of $5 \mathrm{~g} / \mathrm{L}$ for crude enzyme production. The culture medium $(100 \mathrm{~mL})$ was added in an Erlenmeyer flask and adjusted to $\mathrm{pH}$ 6.2. The flask was covered with aluminum foils. The culture medium was autoclaved using the Tuttnauer $28 \mathrm{~L}$ Bench Top Autoclave (Lab Gear, Brisbane, Australia) at $121{ }^{\circ} \mathrm{C}$ for $15 \mathrm{~min}$. One mycelial plug of the stock culture $(1 \times 1 \mathrm{~cm})$ was transferred from the malt extract agar plate to the flask. The liquid culture was maintained at a temperature and mixing rate of $28^{\circ} \mathrm{C}$ and $70 \mathrm{rpm}$, respectively, for eight days. The medium containing laccase enzyme was harvested and stored at $4{ }^{\circ} \mathrm{C}$ in a sterilized bottle. Enzymatic activity of this solution was measured from day 4 of the culture period according to the enzymatic activity assay in Section 2.5.1.

Malt extract agar (Merck, Darmstadt, Germany) was used to develop the solid culture for crude enzyme production. The culture medium was prepared in the same fashion as the liquid culture (i.e., at a concentration of $5 \mathrm{~g} / \mathrm{L}$ ). After the autoclave step, the medium cooled and solidified on the flask. One piece of the stock culture $(1 \times 1 \mathrm{~cm})$ was transferred from the malt extract agar plate to the flask. The flask was incubated in an incubator at $28{ }^{\circ} \mathrm{C}$ and $60 \%$ humidity. On day 4 of the incubation period, mycelium developed to cover the agar surface. Autoclaved Milli-Q water $(100 \mathrm{~mL})$ was added into the flask. The produced enzyme laccase from the agar dissolved into the water at the bottom, while the agar with mycelium floated on the top. Enzymatic activity was measured from every day from day 4 to day 8 . At the end of day 8 , the liquid was decanted into a sterile container and stored at $4{ }^{\circ} \mathrm{C}$.

\subsection{Emerging Contaminants}

A set of emerging contaminants (i.e., 31 compounds) categorized into six groups, such as pharmaceuticals, personal care products (i.e., UV filters), pesticides, industrial chemicals, natural phytoestrogens, steroid hormones was selected as model compounds. These compounds have different chemical properties, such as phenolic or non-phenolic bearing molecular structures [2]. They have also been reported to occur in wastewater and contaminated water bodies around the world [3].

All compounds were analytical grade ( $>99 \%$ purity, Sigma Aldrich, Sydney, Australia). A stock solution containing $31 \mathrm{ECs}$ at $1 \mathrm{~g} / \mathrm{L}$ each in methanol was prepared and kept in $-18{ }^{\circ} \mathrm{C}$ conditions. This stock solution was used within a month to avoid any degradation. This stock solution was added in Milli-Q water to achieve $5 \mu \mathrm{g} / \mathrm{L}$ concentration of each compound in the feed.

\subsection{Membrane Setup for Enzyme Concentration}

A laboratory scale membrane filtration unit consisted of a Tangential Flow Filters (TFF) cartridge (Millipore, Burlington, MA, USA), a pressure gauge and a master flex pump was employed in this study. The TFF cartridge was made of regenerated cellulose. The molecular weight cut off and surface area of the cartridge was $3 \mathrm{kDa}$ and $0.09 \mathrm{~m}^{2}$, respectively. The cartridge was operated at a recirculation flow rate and pressure of $4 \mathrm{~L} / \mathrm{min}$ and 1 bar, respectively (Figure 1 ).

Crude enzyme extract from liquid and solid culture was used for the enzyme concentration experiment. For this experiment, $2 \mathrm{~L}$ of crude enzyme extract was pumped through the cartridge in the upflow configuration at $1 \mathrm{~L} / \mathrm{min}$ to remove all air bubbles. Then, the flow rate was increased to $4 \mathrm{~L} / \mathrm{min}$ while the back-pressure valve was gently closed to increase the pressure to 1 bar. Under this condition, the permeate flow rate was $10 \mathrm{~mL} / \mathrm{min}$. The crude enzyme extract was concentrated to 1 and $0.3 \mathrm{~L}$ volume. Enzymatic activity in the crude enzyme extract and permeate was measured. 


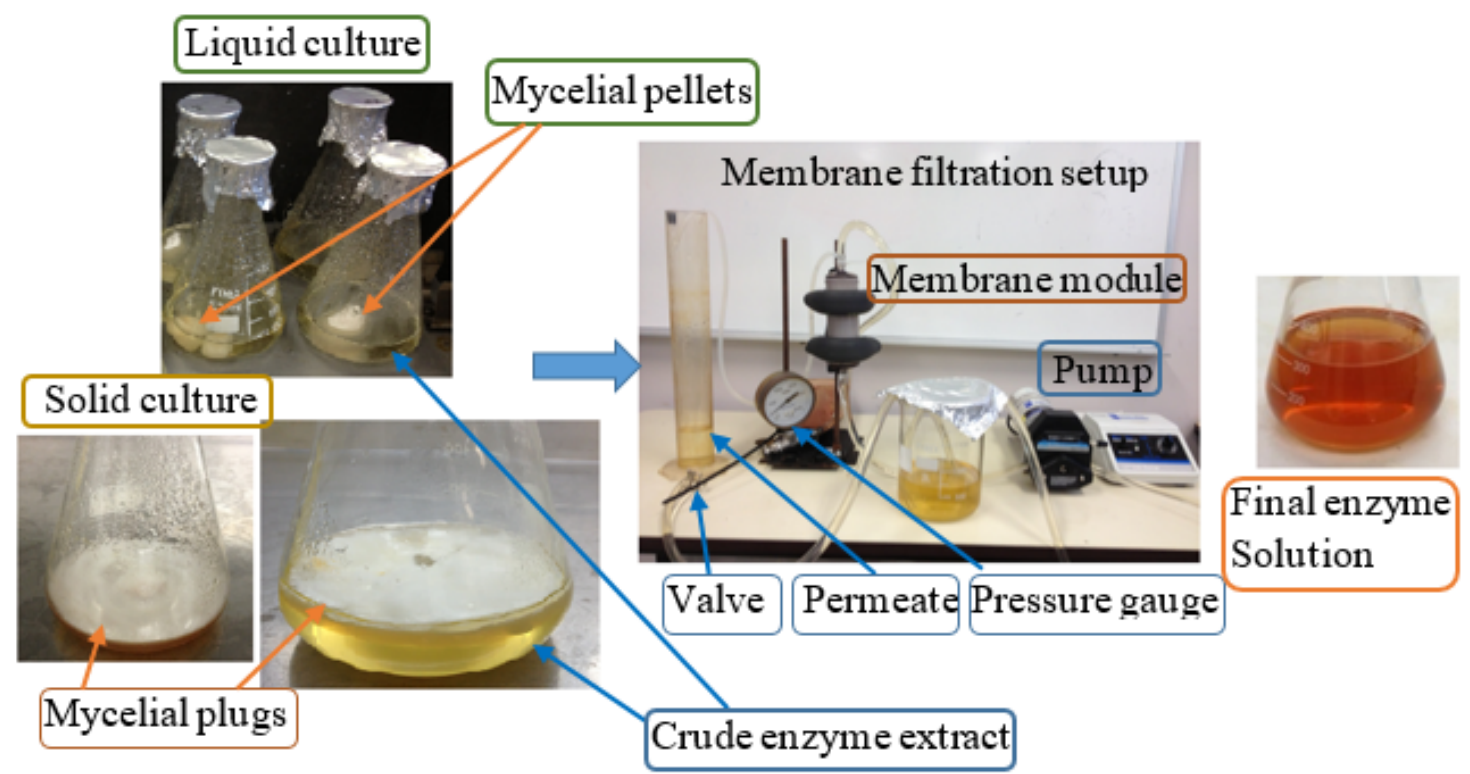

Figure 1. Mycelial pellets and mycelial plugs formation in the liquid and solid culture and the membrane filtration set up to concentrate crude enzyme extract solution.

\subsection{Set Up and Operational Protocol of Enzymatic Membrane Reactor}

The laboratory-scale EMR unit consisted of a Microza UF membrane (Pall Corporation, Melbourne, Australia), a $1 \mathrm{~L}$ glass reactor, two peristaltic pumps (Masterflex L/S, Cole-Parmer, Chicago, IL, USA), and two magnetic stir, a pressure gauge (SPER scientific 840064, Extech equipment Pty. Ltd., Victoria, Australia), a personal computer, an air pump and an air diffusor (Figure 2). The membrane was made of polyacrylonitrile with molecular weight cut off (MWCO) $6 \mathrm{kDa}$, surface area $0.19 \mathrm{~m}^{2}$ and clean water flux $10 \mathrm{~L} / \mathrm{h} \cdot \mathrm{bar}$. The MWCO of this membrane was expected to retain completely laccase enzyme in the EMR experiment.

The EMR system was initiated by adding $1 \mathrm{~L}$ of Milli-Q water into the reactor. Then, a $60 \mathrm{~mL}$ concentrated crude enzyme extract was added, resulting in the laccase activity of $50 \mu \mathrm{M}_{(\mathrm{DMP})} / \mathrm{min}$. The UF membrane was operated in dead-end configuration. One peristaltic pump (i.e., permeate pump) was set up to get the membrane water flux of $1.1 \mathrm{~L} / \mathrm{m}^{2} \cdot \mathrm{h}$. This permeate pump was run on an 8:1 min on:off cycle. The one min off was designed to provide relaxation time (i.e., without filtration) to the membrane. The permeate was collected in a stainless-steel container. The feed solution containing ECs was pumped continuously into the reactor at flow rate of $2.1 \mathrm{~mL} / \mathrm{min}$. The reactor solution (enzyme, ECs and water) was aerated via an air pump and air diffuser to get the dissolved oxygen above $3 \mathrm{mg} / \mathrm{L}$. Air was provided in the reactor because the reaction of laccase required dissolved oxygen molecular as electron acceptor. Without any adjustment, $\mathrm{pH}$ of the reactor solution was $6.8 \pm 0.2$ during the experimental period. The potential membrane fouling was noted by recording the change of transmembrane pressure every $5 \mathrm{~min}$ on a data logger. In the course of the EMR operation, membrane fouling was negligible. This may be due to the operation of the UF membrane at its significant water flux. Enzymatic activity in the reactor was measured regularly. The enzyme solution $(60 \mathrm{~mL}$ laccase/L reactor volume) was manually added (every $12 \mathrm{~h}$ ) in the EMR to maintain laccase activity of 25 to $50 \mu \mathrm{M} / \mathrm{min}$. The hydraulic retention time (i.e., how long laccase react with ECs in the reactor) was maintained at $8 \mathrm{~h}$. The EMR was operated continuously for $105 \mathrm{~h}$. 


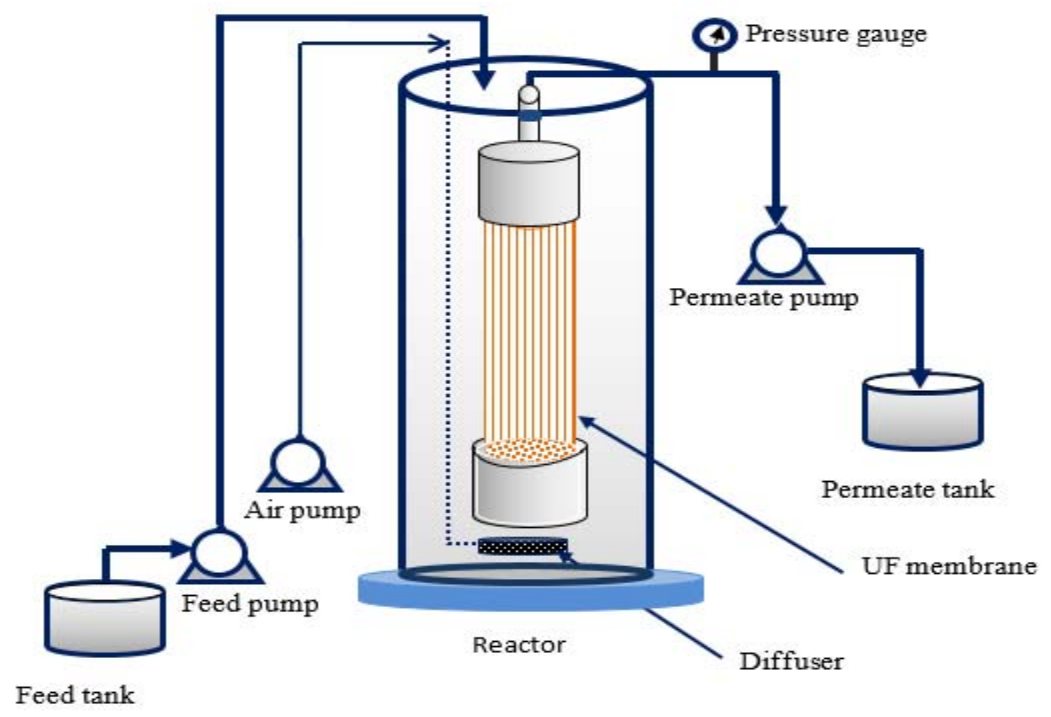

(a)

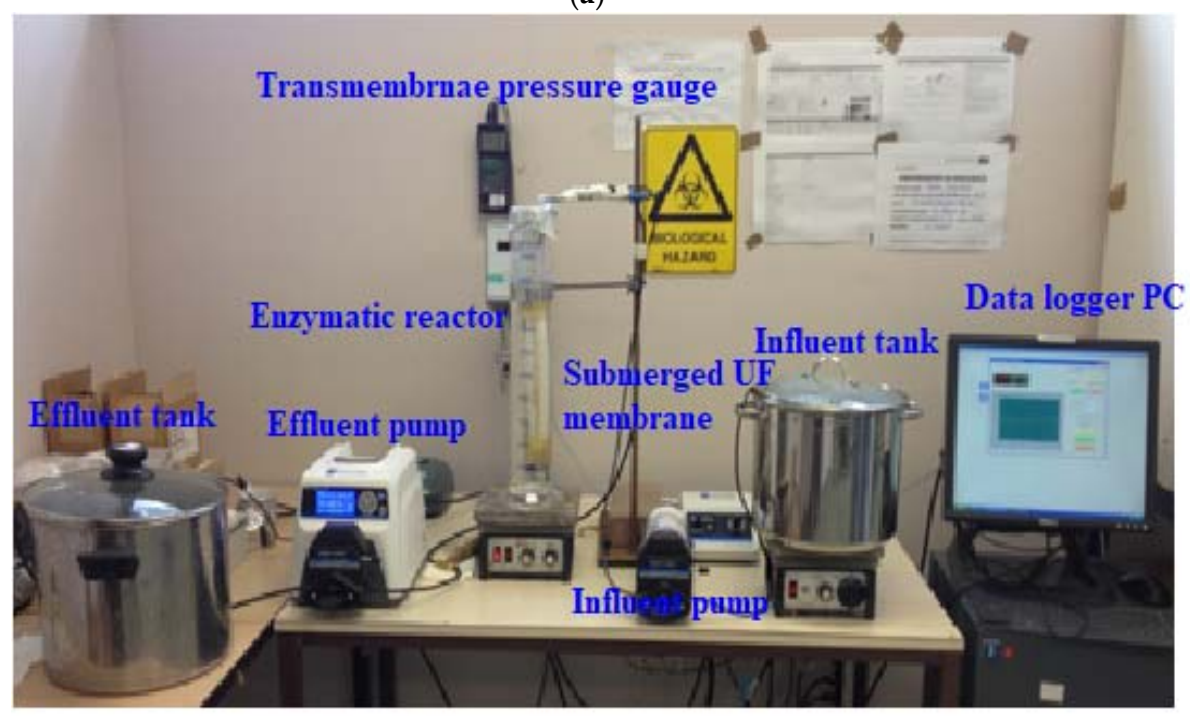

(b)

Figure 2. A schematic diagram (a) and a photography of laboratory scale enzymatic membrane reactor $(\mathbf{b})$.

\subsection{Analytical Methods}

\subsubsection{Enzymatic Activity}

White rot fungi Pleurotus ostreatus (ATCC 34675) secreted mainly laccase in the liquid and solid culture in this study. Laccase activity was measured using the method described in our previous study [18]. In brief, the assay chemicals included $800 \mu \mathrm{L}$ of $10 \mathrm{mM}$ dimethoxyl phenol (DMP) at pH 4.5 (i.e., buffered by sodium citrate), $1200 \mu \mathrm{L}$ of $100 \mathrm{mM}$ sodium citrate and $1000 \mu \mathrm{L}$ laccase solution. The reaction was kept at room temperature $\left(23-24^{\circ} \mathrm{C}\right)$ in two min. The resultant solution was subjected to UV absorbent measurement at $468 \mathrm{~nm}$ by a Shimadzu spectrophotometer (UV 6000, Shimadzu, Kyoto, Japan). The molar extinction coefficient $\varepsilon=49.6 /(\mathrm{mM} \cdot \mathrm{cm})$ was used to calculated final laccase activity in the solution. The laccase activity can vary depending on the used substrate. In this study, laccase activity was expressed in $\mu \mathrm{M}_{(\mathrm{DMP})} / \mathrm{min}$. 


\subsubsection{Emerging Contaminants Measurement}

The EC concentration was measured by a Shimadzu GC/MS QP5000 (Kyoto, Japan) system equipped with a Shimadzu AOC 20i auto sampler (Kyoto, Japan) and a capillary gas chromatography column (i.e., A Phenomenex Zebron ZB-5 (5\% diphenyl, 95\% dimethylpolysiloxane). This column had $30 \mathrm{~m}$ length, $0.25 \mathrm{~mm}$ ID and $\mathrm{df}=0.25 \mu \mathrm{m})$.

Samples $(500 \mathrm{~mL})$ of feed and permeate were collected and subjected to a solid phase extraction method before GC/MS analysis. The solid phase extraction method included a few steps. In step 1, samples were adjusted to $\mathrm{pH} 2.5$ using $0.25 \mathrm{M} \mathrm{H}_{2} \mathrm{SO}_{4}$. In step 2, a $6 \mathrm{~mL} 200 \mathrm{mg}$ Oasic HLB cartridge was pre-conditioned consequently with the following solution $(7 \mathrm{~mL})$ dichloromethane and methanol $(1: 1 v / v), 7 \mathrm{~mL}$ methanol and $7 \mathrm{~mL}$ Milli-Q water. In step 3, the sample was filtered at $15 \mathrm{~mL} / \mathrm{min}$ through the cartridges, allowing the absorption of ECs on the cartridges. In step 4, the cartridges were dried under nitrogen gas stream.

The absorbed ECs on the cartridge were eluted using $7 \mathrm{~mL}$ methanol and $7 \mathrm{~mL}$ mixture of methanol and dichloromethane $(1: 1 v / v)$. The resultant solution in $5 \mathrm{~mL}$ amber bottle was evaporated at $40{ }^{\circ} \mathrm{C}$ in a water batch with a gentle flow of nitrogen gas until dryness. Then, $200 \mu \mathrm{L}$ of pure methanol was added into the bottle to dissolve the ECs. Bisphenol A-d16 $(5 \mu \mathrm{g})$ was added into the bottle as the internal standard. The resultant solution was evaporated to dryness one more time under same conditions as above. Finally, $100 \mu \mathrm{L}$ of N,O-Bis(trimethylsilyl)trifluoroacetamide (1\% trimethylchlorosilane) plus $100 \mu \mathrm{L}$ of pyridine was added in the bottle. The final solution was subjected to the GC-MS analysis. The GC-MS set up method for the detection of ECs was described in our previous study [2]. Our method has a quantitative detection limit in the range of 1 to $20 \mathrm{ng} / \mathrm{L}$ depending on compounds.

The removal efficiency of ECs by the EMR was calculated as:

$$
R=100 \times\left(1-\frac{C_{E f f}}{C_{I n f}}\right)
$$

where $R=$ removal efficiency, $C_{\text {Inf }}=\mathrm{EC}$ concentration in influent and $C_{E f f}=\mathrm{EC}$ concentration in the permeate.

\section{Results and Discussion}

\subsection{Liquid vs. Solid Culture}

The solid culture produced greater enzyme than the liquid culture (Figure 3) because white rot fungi naturally grow on moist solid materials. In the past, fungal cultivation in free-flowing water was researched as a means to develop fungal bioreactors [19]. This approach enabled the direct utilization of enzymes for wastewater treatment and eliminated the need for enzyme purification. However, cultivating fungi in liquid failed to maximize the fungal biomass's potential to produce powerful enzymes. The marginal increase in enzyme production of solid culture was significantly higher than that of the liquid culture (Figure 3). This clearly indicates that fungi thrive better in solid than liquid state. 


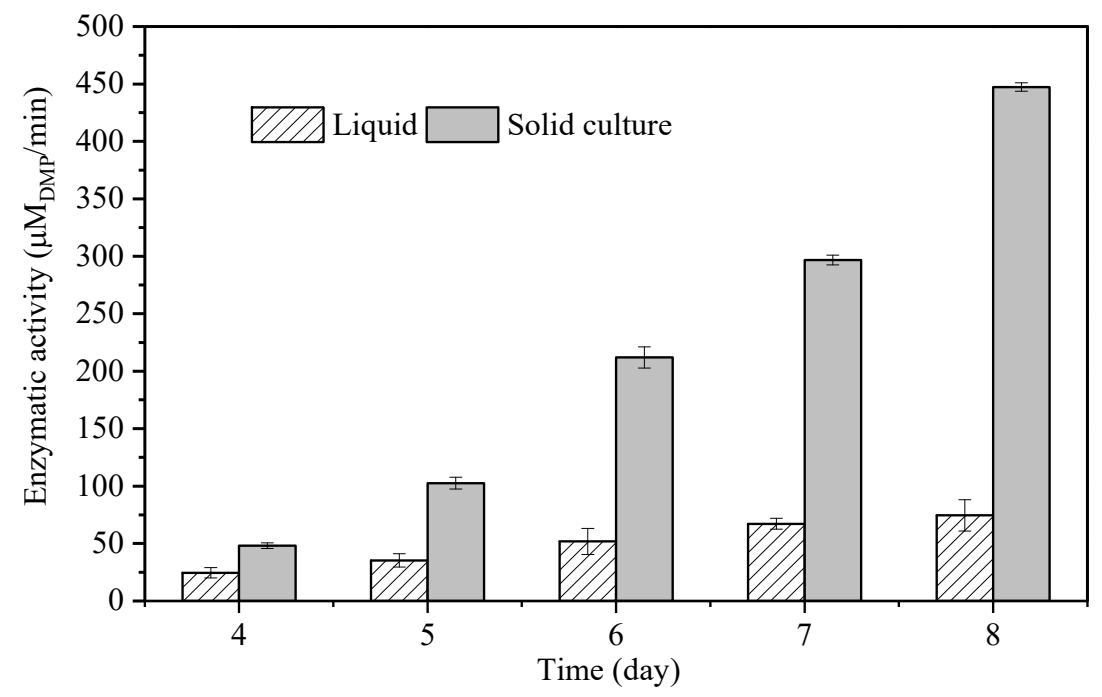

Figure 3. Enzymatic activity in the crude solution from liquid and solid culture. Note, $100 \mathrm{~mL}$ of Milli-Q water was added in the solid culture from day 4 . The data were the average and standard deviation of five cultures.

\subsection{Enhance Enzymatic Activity by Membrane Process}

Crude enzyme laccase from liquid and solid culture can be effectively concentrated using the membrane configuration in this study (Figure 4). The initial crude enzyme (2 L) was concentrated to 1 and $0.3 \mathrm{~L}$, resulting in 6.6 folds increment in enzymatic activity. Initial laccase activity of the crude from liquid culture was increased from 74 to $496 \mu \mathrm{M}_{(\mathrm{DMP})} / \mathrm{min}$, while that of solid culture increased from 447 to $2980 \mu \mathrm{M}_{(\mathrm{DMP})} / \mathrm{min}$. The high laccase activity in the concentrated crude enzyme solution will facilitate the operation of the EMR (Section 3.3), since periodical addition of enzyme is necessary. It is also anticipated that high laccase activity can be achieved if the solution volume continuous to decrease. In a previous study, an UF membrane $(10 \mathrm{kDa})$ provided 20 -fold concentration of crude laccase solution from a white-rot fungi Trametes versicolor [20]. The authors achieved the recovery of $97.5 \%$ of the activity in $50 \mathrm{~mL}$ volume from $1 \mathrm{~L}$ crude solution. The UF filtration process relies solely on size exclusion. The utilized UF membrane has molecular weight cut off significantly lower than that of the enzyme. Our results are in agreement with peer literature review studies on enzyme concentration (e.g., laccase, manganese peroxidase and lignin peroxidase) [21,22].

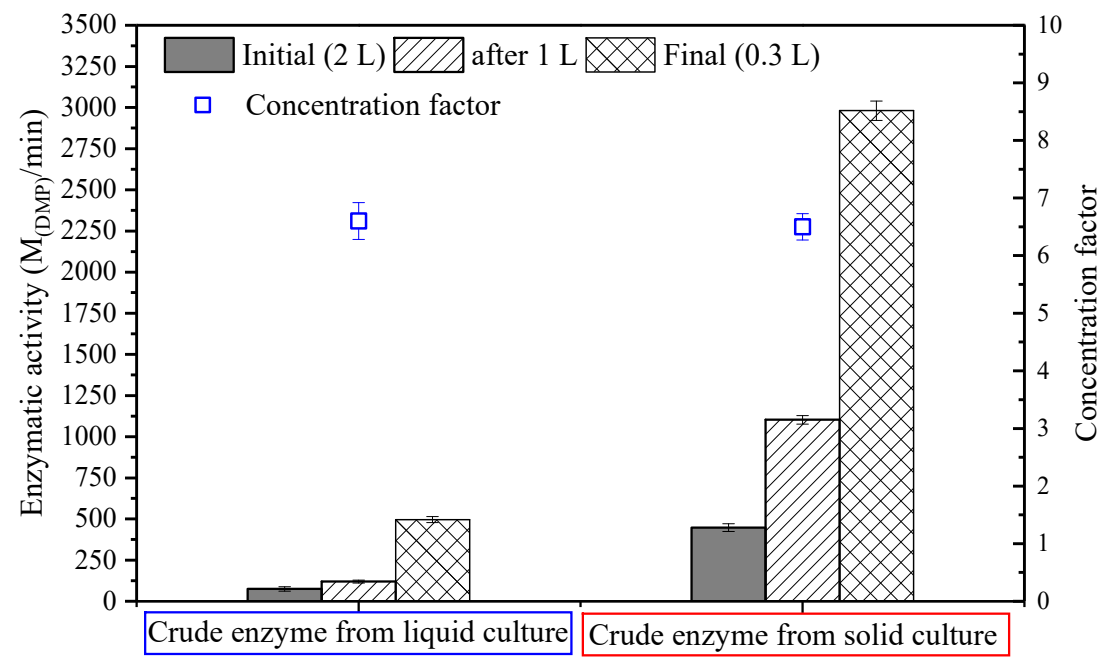

Figure 4. Laccase activity profiles at different solutions. The concentration factor was the ratio of the final over initial laccase activity. The data were the average and standard deviation of three measurements. 
Laccase activity loss in this membrane filtration was negligible. The laccase activity in the final solution was proportional to the reduction in the volume (i.e., from 2 to $0.3 \mathrm{~L}$ ). This observation indicated that no enzyme was lost during the concentration. We observed no laccase activity in the permeate (data not shown). The potential enzyme adsorption on the membrane was not measured; however, the observation of laccase activity in the final solution indicated that adsorption of enzyme on the membrane was negligible. Thus, the membrane process was suitable for the concentration of crude enzyme laccase.

\subsection{Performance of Produced Enzyme on Emerging Contaminants Removal}

\subsubsection{Enzymatic Retention by the UF Membrane}

The EMR's UF membrane completely retained P. ostreatus laccase (Figure 4). Over the operation period of $112 \mathrm{~h}$, no trace of laccase was detected in the permeate given that the UF membrane's MWCO $(6 \mathrm{kDa})$ was far smaller than the molecular weight of laccase (i.e., $67 \mathrm{kDa}$ ) [23]. Previous studies also reported complete enzyme retention by EMRs. Clearly, membrane MWCO and enzyme size are important characteristics that must be considered in EMR design [13,24,25].

\subsubsection{Importance of Highly Concentrated Stock Enzyme Solution}

The availability of a highly concentrated crude enzyme solution was critical to the smooth operation of the EMR. This was because enzymatic activity inside the EMR decreased over time. The enzymatic activity in the EMR decreased by $50 \%$ within the first $16 \mathrm{~h}$ operation $(54 \pm 2.3$ to $26 \pm 4.5 \mu \mathrm{M} / \mathrm{min}$ ) (Figure 5). Hence, regular laccase addition was needed to maintain enzymatic activity and EC removal. This was readily achieved by adding small volumes of concentrated crude enzyme solution. In this study, enzymatic activity was kept within 25 to $55 \mu \mathrm{M} / \mathrm{min}$ by adding $60 \mathrm{~mL}$ of the concentrated crude enzyme into the $1 \mathrm{~L}$ reactor every $12 \mathrm{~h}$. Because only small increments of enzyme solution were required, there was minimal impact on reactor water level and hydraulic retention time. This would not have been possible without high output enzyme cultivation via solid culture and the enzyme concentration step.

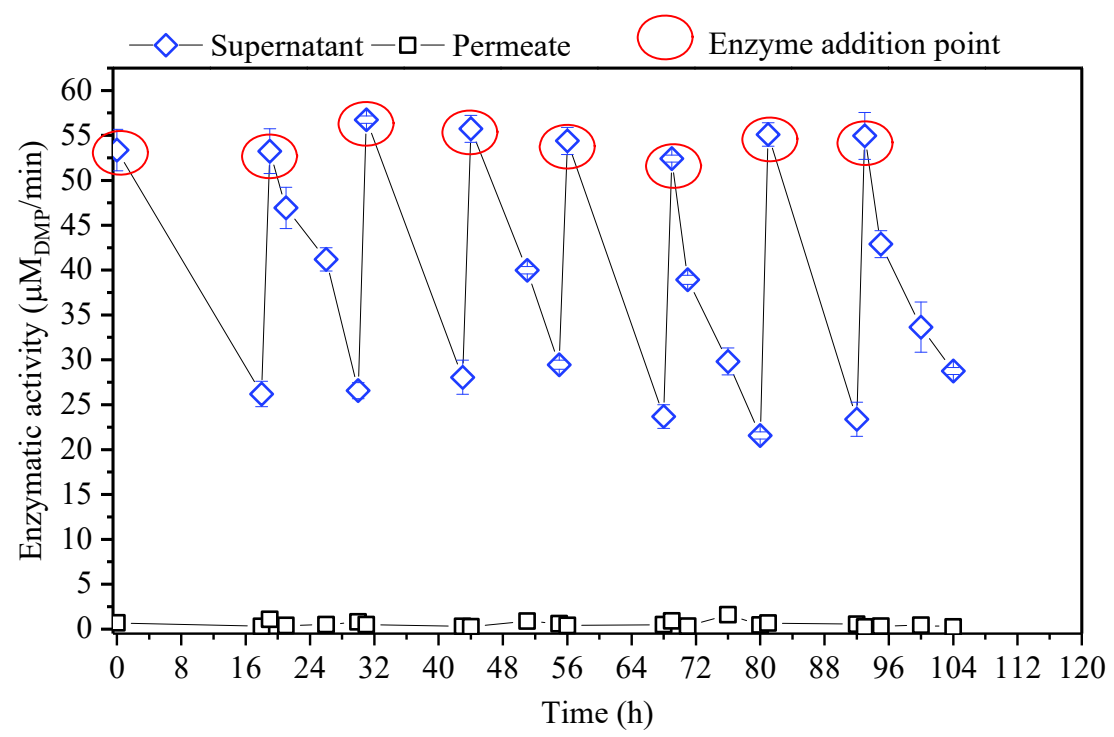

Figure 5. Enzymatic activity in the enzymatic membrane reactor (EMR) supernatant and permeate during the $112 \mathrm{~h}$ operation. The data were the average and standard deviation of three measurements.

Enzyme inactivation in continuous reactors is imminent due to several physicochemical and biological factors $[25,26]$. Operating temperature, shear rate and flow geometry can deform enzyme structure. Adsorption and deposition on membrane surface could reduce the enzyme activity in the 
reactor. Chemical reactions between the laccase and pollutants eventually deactivate the enzyme [27]. Free radicals generated during the catalytic conversion of phenols and amines bearing compounds could oxidize the active site of laccase [27,28]. Microbial growth or contamination in the EMR could degrade laccase. The denaturation of laccase in the EMR system could be the combination of these factors. Detailed contributions of each factor to the overall laccase activity loss are not available in the peer-reviewed literature. However, research efforts to enhance the durability of laccase are on this trajectory with a few developed strategies (e.g., immobilization on membrane, addition of preservative chemical) [29].

\subsubsection{Removal of ECs in EMR}

The EMR removed a broad spectrum of emerging contaminants (i.e., 31 compounds and 6 groups). The removal efficiency depended on EC properties (Figure 6). Industrial chemicals, UV filters, phytoestrogens and steroid hormones were effectively removed (i.e., $>90 \%$ ). Meanwhile, the removal of compounds in the pesticide and pharmaceutical groups varied from $10 \%$ to above $90 \%$ (Figure 6).

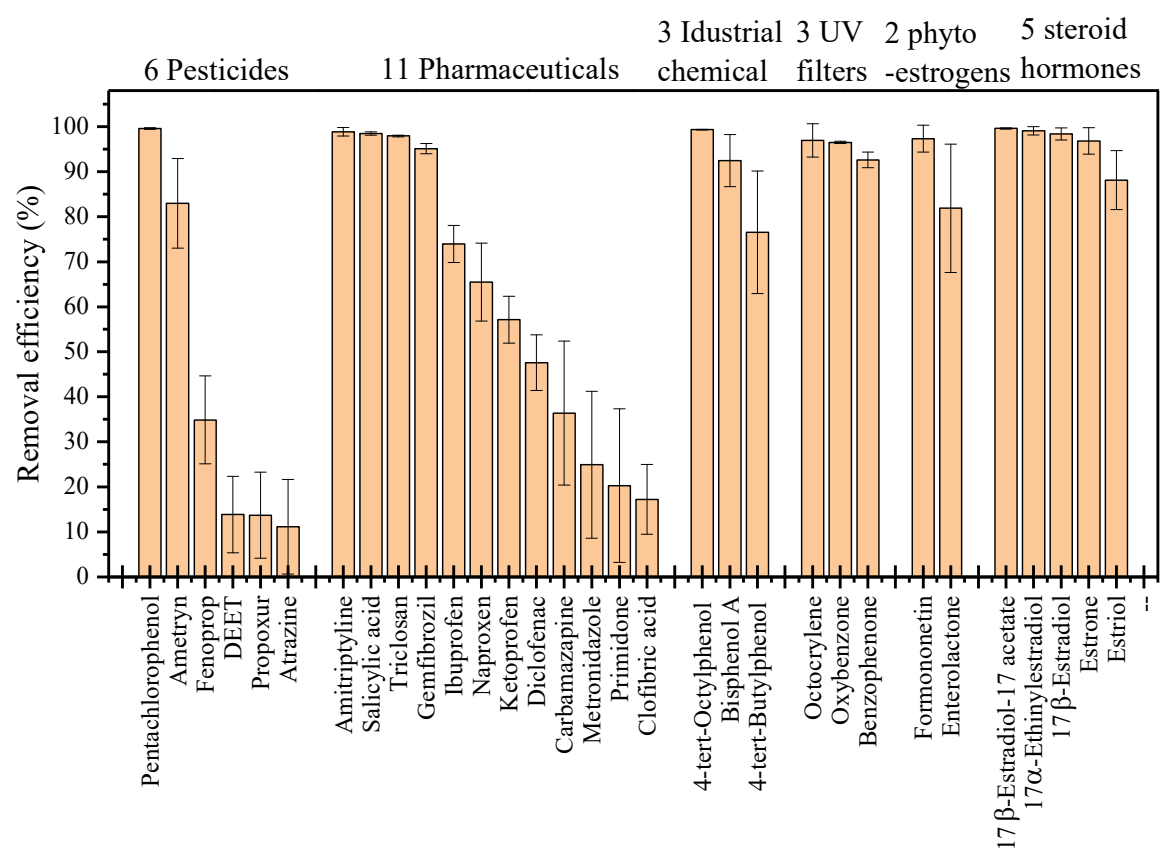

Figure 6. Removal efficiency of 31 emerging contaminants by enzymatic membrane bioreactor with crude enzyme extract from Pleurotus ostreatus. The data were the average and standard deviation of six samples. The samples were collected at 22, 44 and $88 \mathrm{~h}$ of the EMR operation.

The crude enzyme from P. ostreatus efficiently degraded phenolic bearing compounds (Figure 6). The catalytic reaction of laccase with the substrate results in a reductive cleavage of a dioxygen bond. In this reaction, the copper metal atoms within the laccase structure play an important role in the reduction of oxygen to water. There are three copper types in the laccase molecule: one type $1(\mathrm{Cu} 1)$, one type $2(\mathrm{Cu} 2)$ and two type $3(\mathrm{Cu} 3)$. $\mathrm{Cu} 1$ is the most important electron acceptor in the oxidation. Its action governs the catalytic rate. Previous studies have identified that the redox potential of $\mathrm{Cu} 1$ is between 0.42 and $0.79 \mathrm{mV}$. This redox potential could explain the laccase reaction on phenolic compounds [30]. Mehra et al. [31] also suggested that phenolic substrates have a high affinity to the $\mathrm{Cu} 1$ site of the laccase for electron transfer. The variation in the redox potential of $\mathrm{Cu} 1$ could explain the removal efficiency of phenolic substrates from different studies. Laccase from bacteria, plants and insects is characterized by a low redox potential, whereas white rot fungi laccase is high redox. In our previous EMR study, laccase from Aspergillus oryzae (redox potential of $0.28 \mathrm{mV}$ ) removed $40 \%$ to $60 \%$ of 
for example salicylic acid, formononetin and pentachlorophenol [2]. In this study, above $95 \%$ removal efficiency was achieved for these compounds. The results highlight the importance of laccase selection.

The removal efficiency of pesticide and pharmaceutical compounds by the EMR varied significantly from $10 \%$ to $90 \%$ due to their different chemical structures. Amongst six pesticides, only one phenolic bearing compound, pentachlorophenol, was removed to $99 \%$ (Figure 6). Meanwhile, pharmaceutical compounds such as amitriptyline, salicylic acid, triclosan and gemfibrozil were effectively removed. Amongst these, only salicylic acid and triclosan contains phenolic moiety in their structures. This observation suggests that apart from the oxidation of phenolic moiety, other mechanisms may contribute to the high removal efficiency of these compounds in the EMR system.

The chemical adsorption of EC compounds on the membrane surface and/or on membrane gel layer can contribute to their overall removal. During the filtration process, an enzymatic gel layer can deposit on the membrane surface. This gel layer can perform as an active adsorbent (i.e., adsorb and oxidize). The affinity to the gel layer depends on compound hydrophobicity. In this regard, pentachlorophenol, triclosan, oxybenzone, octocrylene and benzophenone are highly hydrophobic compounds (their log D values higher than 3). This finding is consistent with our previous studies using commercially available laccase [2]. Although the application of concentrated crude enzyme in the EMR can lead to high removal efficiency of emerging contaminants, the low removal efficiency of some compounds (i.e., pesticides and pharmaceuticals) indicates a downstream treatment of EMR permeate is required. It also noted that water matric (i.e., wastewater containing other pollutants such as metals, organic carbon, organic salts, suspended solid) could affect laccase activity. However, this research is beyond the scope of the current study.

\section{Conclusions}

This study demonstrated the effectiveness of solid culture over liquid culture of white rot fungi for laccase production. A six fold increment in the enzymatic activity was achieved under the same culture period (i.e., 8 days). The produced crude enzyme was concentrated by UF membrane ( $3 \mathrm{kDa})$, providing a new concentrated crude enzyme at laccase activity of $2980 \mu \mathrm{M}_{(\mathrm{DMP})} / \mathrm{min}$. The concentrated laccase activity was 6.6 times that of the initial value. The results also suggest no loss of enzyme during the concentration process. The concentrated crude enzyme was applied in the EMR for the continuous removal of 31 emerging contaminants. The UF membrane completely retained laccase, but denaturation in laccase activity was observed. An enzyme re-addition strategy was developed by adding $60 \mathrm{~mL}$ of crude solution ( $6 \%$ reactor volume) to maintain laccase activity. Under this operation, the EMR effectively removed of phenolic compounds such as steroid hormones, industrial chemical, phytoestrogen and UV filters. However, the removal efficiency of major pesticides and pharmaceuticals was low, indicating the limitation of laccase.

Author Contributions: L.N.N.: conceptualization, data curation, writing-original draft. M.T.V.: data curation, formal analysis. M.A.H.J.: writing-review and editing. N.P.: data curation. J.Z.: writing-review and editing. T.J.: writing-review and editing. G.U.S.: writing—review and editing. F.I.H.: writing-review and editing; supervision. H.K.D.N.: writing-review and editing and L.D.N.: writing-review and editing. All authors have read and agreed to the published version of the manuscript.

Funding: This research received no external funding.

Conflicts of Interest: The authors declare no conflict of interest.

\section{References}

1. Schwarzenbach, R.P.; Egli, T.; Hofstetter, T.B.; Von Gunten, U.; Wehrli, B. Global Water Pollution and Human Health. Annu. Rev. Environ. Resour. 2010, 35, 109-136. [CrossRef]

2. Nguyen, L.N.; Hai, F.I.; Price, W.E.; Kang, J.; Leusch, F.D.; Roddick, F.; van de Merwe, J.P.; Magram, S.F.; Nghiem, L.D. Degradation of a broad spectrum of trace organic contaminants by an enzymatic membrane reactor: Complementary role of membrane retention and enzymatic degradation. Int. Biodeterior. Biodegrad. 2015, 99, 115-122. [CrossRef] 
3. Tran, N.H.; Reinhard, M.; Gin, K.Y. Occurrence and fate of emerging contaminants in municipal wastewater treatment plants from different geographical regions-A review. Water Res. 2018, 133, 182-207. [CrossRef] [PubMed]

4. Bolong, N.; Ismail, A.F.; Salim, M.R.; Matsuura, T. A review of the effects of emerging contaminants in wastewater and options for their removal. Desalination 2009, 239, 229-246. [CrossRef]

5. Egea-Corbacho, A.; Ruiz, S.G.; Alonso, J.M. Removal of emerging contaminants from wastewater using nanofiltration for its subsequent reuse: Full-scale pilot plant. J. Clean. Prod. 2019, 214, 514-523. [CrossRef]

6. Lopera, A.E.; Ruiz, S.G.; Alonso, J.M. Removal of emerging contaminants from wastewater using reverse osmosis for its subsequent reuse: Pilot plant. J. Water Process Eng. 2019, 29, 100800. [CrossRef]

7. Cristóvão, M.B.; Torrejais, J.; Janssens, R.; Luis, P.; Van der Bruggen, B.; Dubey, K.K.; Mandal, M.K.; Bronze, M.R.; Crespo, J.G.; Pereira, V.J. Treatment of anticancer drugs in hospital and wastewater effluents using nanofiltration. Sep. Purif. Technol. 2019, 224, 273-280. [CrossRef]

8. Coimbra, R.N.; Escapa, C.; Otero, M. Adsorption separation of analgesic pharmaceuticals from ultrapure and waste water: Batch studies using a polymeric resin and an activated carbon. Polymers 2018, 10, 958. [CrossRef]

9. Tadkaew, N.; Hai, F.I.; McDonald, J.A.; Khan, S.J.; Nghiem, L.D. Removal of trace organics by MBR treatment: The role of molecular properties. Water Res. 2011, 45, 2439-2451. [CrossRef]

10. Nguyen, L.N.; Hai, F.I.; Kang, J.; Price, W.E.; Nghiem, L.D. Removal of emerging trace organic contaminants by MBR-based hybrid treatment processes. Int. Biodeterior. Biodegrad. 2013, 85, 474-482. [CrossRef]

11. Zdarta, J.; Jankowska, K.; Wyszowska, M.; Kijeńska-Gawrońska, E.; Zgoła-Grześkowiak, A.; Pinelo, M.; Meyer, A.S.; Moszyński, D.; Jesionowski, T. Robust biodegradation of naproxen and diclofenac by laccase immobilized using electrospun nanofibers with enhanced stability and reusability. Mater. Sci. Eng. C 2019, 103, 109789.

12. Tran, N.H.; Urase, T.; Kusakabe, O. Biodegradation characteristics of pharmaceutical substances by whole fungal culture trametes versicolor and its laccase. J. Water Environ. Technol. 2010, 8, 125-140.

13. Nguyen, L.N.; Hai, F.I.; Price, W.E.; Leusch, F.D.; Roddick, F.; McAdam, E.J.; Magram, S.F.; Nghiem, L.D. Continuous biotransformation of bisphenol A and diclofenac by laccase in an enzymatic membrane reactor. Int. Biodeterior. Biodegrad. 2014, 95, 25-32.

14. Adekunle, A.E.; Zhang, C.; Guo, C.; Liu, C.Z. Laccase Production from Trametes versicolor in Solid-State Fermentation of Steam-Exploded Pretreated Cornstalk. Waste Biomass Valorization 2017, 8, 153-159. [CrossRef]

15. Galhaup, C.; Wagner, H.; Hinterstoisser, B.; Haltrich, D. Increased production of laccase by the wood-degrading basidiomycete Trametes pubescens. Enzym. Microb. Technol. 2002, 30, 529-536. [CrossRef]

16. Lloret, L.; Eibes, G.; Feijoo, G.; Moreira, M.T.; Lema, J.M. Degradation of estrogens by laccase from Myceliophthora thermophila in fed-batch and enzymatic membrane reactors. J. Hazard. Mater. 2012, 213, 175-183. [CrossRef]

17. Mendoza, L.; Jonstrup, M.; Hatti-Kaul, R.; Mattiasson, B. Azo dye decolorization by a laccase/mediator system in a membrane reactor: Enzyme and mediator reusability. Enzym. Microb. Technol. 2011, 49, 478-484. [CrossRef]

18. Hai, F.I.; Yamamoto, K.; Nakajima, F.; Fukushi, K. Application of a GAC-coated hollow fiber module to couple enzymatic degradation of dye on membrane to whole cell biodegradation within a membrane bioreactor. J. Membr. Sci. 2012, 389, 67-75.

19. Nguyen, L.N.; Hai, F.I.; Yang, S.; Kang, J.; Leusch, F.D.; Roddick, F.; Price, W.E.; Nghiem, L.D. Removal of trace organic contaminants by an MBR comprising a mixed culture of bacteria and white-rot fungi. Bioresour. Technol. 2013, 148, 234-241. [CrossRef]

20. Antecka, A.; Blatkiewicz, M.; Boruta, T.; Górak, A.; Ledakowicz, S. Comparison of downstream processing methods in purification of highly active laccase. Bioprocess Biosyst. Eng. 2019, 42, 1635-1645. [CrossRef]

21. Cheng, X.; Jia, R.; Li, P.; Tu, S.; Zhu, Q.; Tang, W.; Li, X. Purification of a new manganese peroxidase of the white-rot fungus Schizophyllum sp. F17, and decolorization of azo dyes by the enzyme. Enzym. Microb. Technol. 2007, 41, 258-264. [CrossRef]

22. Gottschalk, L.M.; Bon, E.P.; Nobrega, R. Lignin Peroxidase from Streptomyces viridosporus T7A: Enzyme Concentration Using Ultrafiltration. In Biotechnology for Fuels and Chemicals; Humana Press: Totowa, NJ, USA, 2008. 
23. Hublik, G.; Schinner, F. Characterization and immobilization of the laccase from Pleurotus ostreatus and its use for the continuous elimination of phenolic pollutants. Enzym. Microb. Technol. 2000, 27, 330-336. [CrossRef]

24. Chhabra, M.; Mishra, S.; Sreekrishnan, T.R. Laccase/mediator assisted degradation of triarylmethane dyes in a continuous membrane reactor. J. Biotechnol. 2009, 143, 69-78. [PubMed]

25. Rios, G.M.; Belleville, M.P.; Paolucci, D.; Sanchez, J. Progress in enzymatic membrane reactors-A review. J. Membr. Sci. 2004, 242, 189-196.

26. Paolucci-Jeanjean, D.; Belleville, M.P.; Rios, G.M. A comprehensive study of the loss of enzyme activity in a continuous membrane reactor-Application to starch hydrolysis. J. Chem. Technol. Biotechnol. 2001, 76, 273-278.

27. Arregui, L.; Ayala, M.; Gómez-Gil, X.; Gutiérrez-Soto, G.; Hernández-Luna, C.E.; de los Santos, M.H.; Levin, L.; Rojo-Domínguez, A.; Romero-Martínez, D.; Saparrat, M.C.; et al. Laccases: Structure, function, and potential application in water bioremediation. Microb. Cell Factories 2019, 18, 200.

28. Kurniawati, S.; Nicell, J.A. A comprehensive kinetic model of laccase-catalyzed oxidation of aqueous phenol. Biotechnol. Prog. 2009, 25, 763-773.

29. Zdarta, J.; Meyer, A.S.; Jesionowski, T.; Pinelo, M. Developments in support materials for immobilization of oxidoreductases: A comprehensive review. Adv. Colloid Interface Sci. 2018, 258, 1-20.

30. Jeon, J.R.; Baldrian, P.; Murugesan, K.; Chang, Y.S. Laccase-catalysed oxidations of naturally occurring phenols: From in vivo biosynthetic pathways to green synthetic applications. Microb. Biotechnol. 2012, 5, 318-332. [CrossRef]

31. Mehra, R.; Muschiol, J.; Meyer, A.S.; Kepp, K.P. A structural-chemical explanation of fungal laccase activity. Sci. Rep. 2018, 8, 17285. [CrossRef]

(C) 2020 by the authors. Licensee MDPI, Basel, Switzerland. This article is an open access article distributed under the terms and conditions of the Creative Commons Attribution (CC BY) license (http://creativecommons.org/licenses/by/4.0/). 